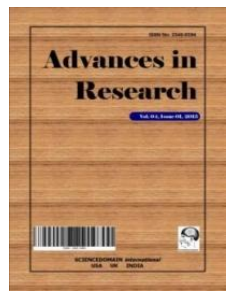

\title{
Advances in Research
}

13(4): 1-11, 2018; Article no.AIR.39175

ISSN: 2348-0394, NLM ID: 101666096

\section{Common octopus (Octopus vulgaris) Performance When Including Fasting on Feeding Schemes: Preliminary Data Regarding a Formulated Feed}

\author{
Tania Rodríguez-González ${ }^{1,2^{*}}$, Jesús Cerezo Valverde ${ }^{1}$, António V. Sykes ${ }^{2}$ \\ and Benjamín García García ${ }^{1}$ \\ ${ }^{1}$ Instituto Murciano de Investigación y Desarrollo Agrario y Alimentario (IMIDA), Marine Aquaculture \\ Station, Carretera del Puerto s/n, 20740, San Pedro del Pinatar, Murcia, Spain. \\ ${ }^{2}$ Centro de Ciências do Mar (CCMAR), Universidade do Algarve, Campus de Gambelas, 8005-139,
}

Faro, Portugal.

Authors' contributions

This work was carried out in collaboration between all authors. Authors TRG, JCV, AVS and BGG designed the study, performed the statistical analysis, wrote the protocol and wrote the first draft of

the manuscript. Author TRG managed the analyses of the study and the literature searches. All authors read and approved the final manuscript.

Article Information

DOI: $10.9734 / A I R / 2018 / 39175$

Editor(s):

(1) Rauquírio André Albuquerque Marinho da Costa, Institute of Coastal Studies, Federal University of Pará, Brazil.

Reviewers:

(1) Jorge Castro Mejia, Universidad Autonoma Metropolitana, México. (2) Riccardo Caprioli, Istituto Zooprofilattico Sperimentale dell'Abruzzo e del Molise Giuseppe Caporale, Italy. Complete Peer review History: http://www.sciencedomain.org/review-history/23065

Short Research Article

Received $2^{\text {nd }}$ November 2017

Accepted $31^{\text {st }}$ January 2018

Published $7^{\text {th }}$ February 2018

\section{ABSTRACT}

The common octopus (Octopus vulgaris) has aroused great interest in recent years as a new species for aquaculture. The current research is focused on developing a formulated feed, although a proper diet management has also promoted rearing success of other commercial cultured species. It is documented that wild animals eat depending on prey availability and most experience fasting in nature. Hence, $O$. vulgaris subadults were subjected to two different feeding schemes, with a similar semi-moist diet, including either 2 (2FDb, control) or 3 (3FDb) non-consecutive days of fasting per week. Growth, feed efficiency (FE), digestibility and condition were assessed after 56 days of rearing. Both feeding schemes promoted similar growth and digestibility $(P>0.05), 100 \%$ of survival and higher food-intake after fasting. Interestingly, feed efficiency (FE) was enhanced with the 3

*Corresponding author: E-mail: taniafoski@gmail.com, tania.rodriguez@carm.es; 
fasting days scheme $(58.6 \%$ vs. $48.3 \%$ for 2 FDb scheme; $P<0.05)$. Results might indicate that $O$. vulgaris has the ability to compensate fasting days through an increase in food intake on the subsequent day or a better use of its reserves. Moreover, a reduction on feeding days might promote a decrease in production costs at commercial scale.

Keywords: Octopus vulgaris; feeding protocol; fasting; growth; feed efficiency; formulated diet; performance.

\section{INTRODUCTION}

The common octopus (Octopus vulgaris) is considered a potential species for industrial aquaculture $[1,2]$. Currently, research is focused on developing a formulated feed, with an adequate nutritional composition and palatability [3-6]. Still, it must be considered that, in nature, cephalopods are subject to fasting [7] but still attain higher growth rates. This points to the possibility of establishing a feeding regime including fasting days when these species individuals are kept in captivity. In fact, this type of feeding scheme is already a common practice in other commercially reared species, such as salmonids [8]. A proper feed management has promoted a decrease in production expenses while maintaining culture success of fish species $[8,9]$ through a compensatory growth strategy [10].

Octopus food intake increases after fasting days, when individuals are fed with either formulated [3,5] or natural diets [11]. Contrariwise, these species display an irregular ingestion pattern when fed daily. In this sense, some days they practically reject all food supplied which might indicate, as occurs in the wild, that this species doesn't need a daily feeding regime. Accordingly, Morillo-Velarde et al. [5] and García-Garrido et al. [12] proved the use of energetic reserves stored in the digestive gland during starvation, principally as triglycerides. In addition, amino acids and carbohydrates can also be used during fasting periods $[13,14]$. This has been reported not only in this species but also in other cephalopods, such as Sepia officinalis [15,16]. A suitable feeding regime for $O$. vulgaris could avoid an excess of lipids storage in the digestive gland when fed with formulated diets $[17,18]$, which might have a negative effect on ingestion and in the condition of individuals in the long term. Moreover, a reduction in nourishing days in feeding schemes also denotes a cost reduction and economic benefits for growing or maintenance of commercial production of this species. In this sense, studies testing feeding schemes that include fasting might allow a better comprehension on how it affects the growth performance. Hence, we tested if an increase in fasting days included in feeding schemes affects octopus production performance.

\section{MATERIALS AND METHODS}

In the present study, two feeding regimes were applied to octopus, reared with the same semimoist diet (Table 1) but fasting either two (2FDb, fasting on Wednesdays and Saturdays, [19]), as control, or three (3FDb, fasting on Mondays, Wednesdays and Saturdays) non-consecutive days per week. Growth, feed efficiency, digestibility and condition of $O$. vulgaris were assessed after 56 days of rearing.

\subsection{Acclimation and Experimental Conditions}

A total of 16 O. vulgaris juveniles were captured by trawling in the Mediterranean Sea (Murcia, SE, Spain), transported to the Instituto Murciano de Investigación y Desarrollo Agrario y Alimentario (IMIDA) facilities and kept in group in 1970L circular tanks for captive acclimation for two weeks. A week before the start of the experiment, octopuses were re-allocated individually in $216 \mathrm{~L}$ circular tanks, of a recirculated seawater system described in [19], and were acclimated to isolation conditions for a week. Until the start of the experiment, individuals were fed to satiety on crab (Carcinus mediterraneus). The experiment was performed at $19.9 \pm 1.5^{\circ} \mathrm{C}$, salinity of $36.8 \%$, dissolved oxygen concentration above $80 \%$ saturation and a photoperiod of 12L: $12 \mathrm{D}$.

Two experimental groups of eight individual replicates were established depending on the feeding regime, being fed to satiety a semi-moist prepared diet, provided as cube/rectangular shaped pieces, previously tested by RodríguezGonzález et al. [19] (see Table 1 for details regarding raw materials and proximate composition). 
Table 1. Basal mixture (\%) and proximate composition (\% dry weight) of freeze-dried bogue (FDb) formulated diet [19]

\begin{tabular}{|c|c|}
\hline Basal mixture (\%) & $\begin{array}{l}\text { Water } \\
\text { Gelatin } \\
{ }^{1} \\
\text { Egg yolk }^{2} \\
\text { Bogue }^{3} \text { (Boo } \\
\text { Squid }^{3} \text { (Todc } \\
\text { Crab }^{3,4} \text { (Car } \\
\text { Fish oil } \\
\text { Glucose }^{5} \\
\text { Starch }^{6}\end{array}$ \\
\hline Proximate composition (\%) & $\begin{array}{l}\text { Moisture } \\
\text { Crude protein } \\
\text { Crude lipid } \\
\text { Ash } \\
\mathrm{NFE}^{7} \\
\mathrm{AlA}^{8} \\
\text { Gross energy } \\
\left.{\mathrm{P} / \mathrm{E}^{9}}^{9} \mathrm{~g} / \mathrm{MJ}\right)\end{array}$ \\
\hline \multicolumn{2}{|c|}{$\begin{array}{l}\text { Data as mean } \pm S D ;{ }^{1} \text { Granulated Gelatin, Bloom } 220 \\
\text { Ginés, Murcia, Spain); }{ }^{2} \text { Egg yolk powder, supplied by A } \\
\text { Spain); }{ }^{3} \text { Freeze-dried ingredients; }{ }^{4} \text { Whole animal freeze } \\
\text { (Alboraya, Valencia, Spain); }{ }^{6} \text { Starch from potato soluk } \\
\text { Vallés, Barcelona, Spain); }{ }^{7} \text { NFE, Nitrogen-free extra } \\
{ }^{9} P / E=\text { proteir }\end{array}$} \\
\hline $\begin{array}{l}\text { Every individual was weighted } \\
\text { weight of } 675 \pm 65 \mathrm{~g}), 28 \text { and } 56 \\
\text { avoid a handling stress. O } \\
\text { individuals were euthanized by } \\
\text { seawater. The experiment was } \\
\text { Project INIA-Project RTA2 } \\
\text { which was approved before the } \\
\text { Directive } 2010 / 63 / \text { EU as nati } \\
\text { Spain. }\end{array}$ & $\begin{array}{l}\text { day } 0 \text { (mean } \\
\text { of rearing to } \\
\text { le last day, } \\
\text { ersion in iced } \\
\text { formed under } \\
00072-00-00 \text {, } \\
\text { y into force of } \\
\text { legislation in }\end{array}$ \\
\hline
\end{tabular}

\subsection{Preparation, Conservation and Water Stability of the Diets}

The formulated diet based on freeze-dried ingredients (diet FDb) was prepared according to Rodríguez-González et al. [19], vacuumpacked and maintained frozen at $-20^{\circ} \mathrm{C}$ until use.

The water stability was defined as feed disintegration percentage (WSI) of dry weight after soaking in seawater for $24 \mathrm{~h}$. WSI was calculated following WSI (\%)= ((DWi - DWf)/DWi)x100, where DWi and DWf are the initial and final dry weights, respectively.

\section{FDb diet}

40


tissue determinations, and another four for whole animal determinations.

The macronutrient composition (moisture, ash, crude protein and lipid content, and nitrogen-free extract, calculated by difference) were determined according to AOAC [20] methodologies as described in RodríguezGonzález et al. [19].

\subsection{Calculated Parameters and Indices}

Growth, ingestion and feed efficiency indices were calculated as follows: (1) Weight gain (Wg; g) $=\mathrm{Wf}-\mathrm{Wi}$, where $\mathrm{Wi}=$ initial weight $(\mathrm{g})$; Wf $=$ final weight (g); (2) Absolute growth rate (AGR; g.day-1) $=(\mathrm{Wf}-\mathrm{Wi}) / \mathrm{t}$, where $\mathrm{t}=$ time in days; $(3)$ Specific growth rate $(\mathrm{SGR} ; \% \mathrm{BW}$.day-1) $=(\mathrm{LnWf}$ - LnWi) x $100 / \mathrm{t}$, where BW refers to body weight; (4) Absolute feeding rate (AFR; g.day-1) $=\mathrm{IF} / \mathrm{t}$, where IF is the Corrected ingestion (IF; wet weight in $g)=$ (dry feed supplied in $g$ uneaten dry feed in $\mathrm{g} \times \mathrm{F}$ ) + moisture feed supplied in $g$ and $F$ is a Correction factor for ingestion $(F)=D W i / D W f$, which considers disaggregation rate in water being $\mathrm{DWi}=$ initial dry weight (g) and DWf = final dry weight (g); (5) Absolute protein or lipid feeding rate: AyFR $($ g.day -1$)=\mathrm{ly} / \mathrm{t}$, where y could be either protein or lipid, ly = ingested protein or lipid (g); (6) Specific feeding rate (SFR; \%BW.day-1) = (AFR $\mathrm{x}$ 100) $/ \mathrm{Wa}$, where $\mathrm{Wa}=$ Average weight in $\mathrm{g}=$ $(\mathrm{Wi}+\mathrm{Wf}) / 2$; (7) Feed efficiency $(\mathrm{FE} ; \%)=(\mathrm{Wf}-$ Wi) $\times 100$ / IF; (8) Feed conversion ratio: FCR = IF / (Wf - Wi); (9) Productive value for lipids or proteins (LPV and PPV, respectively; \%) = $100 \mathrm{x}$ retained (Lipids or Proteins) / Intake (Lipids or Proteins) and (10) Digestive gland index (DGI; $\%)=D G W \times 100 / \mathrm{Wf}$, where $\mathrm{DGW}$ refers to digestive gland weight $(\mathrm{g})$.

The variation of the daily food intake was analysed through the instantaneous feeding rate (IFR), according to [11]. Similarly, the variation of the weekly intake was analysed through the feeding rate per week (WFR), expressed as a percentage of the weekly ingested food, by each, with respect to its body weight estimation, from the obtained SGR for each one, at the 4th day of each week.

\subsection{Statistical Analysis}

The obtained results were expressed as mean \pm standard deviation (SD). Normality and homogeneity of variances were tested using the
Shapiro-Wilk test and the Levene's test [21], respectively. An arcsine square root transformation was applied on percentages and data when normality and/or homoscedasticity where not met. A t-test for independent samples [21] was used to compare: growth, ingestion and feed efficiency indices for each experimental group; the collected faeces macronutrient composition; digestibility; and the proximate composition in octopus tissues fractions (digestive gland, muscle and whole animal). A Mann-Whitney $U$ test was used when a normal distribution and/or homogeneity of the variances were not achieved after arcsine square root transformation [21].

\section{RESULTS AND DISCUSSION}

\subsection{Results}

The semi-moist formulated diet (FDb, Table 1) was accepted by both groups and promoted growth, faeces production and $100 \%$ survival. Ingestion and growth were similar between experimental groups considering the lapses between samplings and the whole experimental period ( $P>0.05$; Table 2). Nonetheless, the 3FDb group presented higher FE and PPV than 2FDb $(P<0.05$, Table 2) without differences on animal condition.

The macronutrient composition of faeces was similar between both feeding regimes $(P>0.05$; Table 3). Alike, the apparent digestibility coefficients (dry matter, protein, lipids and nitrogen-free extract) were similar ( $P>0.05$; Table 3) and the whole animal, digestive gland and muscle proximate composition were also similar between groups $(P>0.05$, Table 4).

When Instantaneous Feeding Rate (IFR) values were compared on a daily basis (Fig. 1), significant differences were identified $(P<0.05)$. Both groups displayed the highest IFR peaks after fasting. Additionally, the 2FDb group ingestion exceeded 4\% IFR in some cases.

The Feeding Rate per Week (WFR) displayed dissimilarities between different weeks (Fig. 2) but showed a similar ingestion trend, which was characterized by an intake reduction followed by an increase in the same weeks. In any case, ingestion and growth were similar for both fasting regimes through all the experimental period ( $P>0.05$, Table 2). 
Table 2. Growth, ingestion and feed efficiency for two (2FDb) or three (3FDb) days of fasting

\begin{tabular}{|c|c|c|c|}
\hline Index/Diet & & 2FDb & 3FDb \\
\hline \multirow[t]{13}{*}{ Growth } & W(g) & & \\
\hline & Day 0 & $661 \pm 62$ & $689 \pm 67$ \\
\hline & Day 28 & $872 \pm 102$ & $939 \pm 126$ \\
\hline & Day 56 & $1029 \pm 144$ & $1127 \pm 123$ \\
\hline & $W g_{0-28}(g)$ & $211 \pm 63$ & $249 \pm 70$ \\
\hline & $\mathrm{AGR}_{0-28}$ (g/day) & $7.55 \pm 2.27$ & $8.91 \pm 2.50$ \\
\hline & $\mathrm{SGR}_{0-28}(\% \mathrm{BW} /$ day $)$ & $0.98 \pm 0.25$ & $1.09 \pm 0.22$ \\
\hline & $\mathrm{Wg}_{28-56}(\mathrm{~g})$ & $157 \pm 71$ & $188 \pm 49$ \\
\hline & $\mathrm{AGR}_{28-56}$ (g/day) & $5.59 \pm 2.52$ & $6.71 \pm 1.76$ \\
\hline & $\mathrm{SGR}_{28-56}(\% \mathrm{BW} /$ day $)$ & $0.58 \pm 0.22$ & $0.66 \pm 0.19$ \\
\hline & $W g_{0-56}(g)$ & $368 \pm 112$ & $437 \pm 80$ \\
\hline & $\mathrm{AGR}_{0-56}$ (g/day) & $6.57 \pm 2.01$ & $7.81 \pm 1.42$ \\
\hline & $\mathrm{SGR}_{0-56}(\% \mathrm{BW} /$ day$)$ & $0.78 \pm 0.19$ & $0.88 \pm 0.12$ \\
\hline \multirow[t]{4}{*}{ Ingestion } & $\mathrm{AFR}_{0-56}$ (g/day) & $13.41 \pm 2.07$ & $13.37 \pm 2.46$ \\
\hline & APFR $_{0-56}$ (g/day) & $5.01 \pm 0.77$ & $5.00 \pm 0.92$ \\
\hline & $\mathrm{ALFR}_{0-56}(\mathrm{~g} / \mathrm{day})$ & $1.68 \pm 0.26$ & $1.68 \pm 0.31$ \\
\hline & $\mathrm{SFR}_{0-56}(\% \mathrm{BW} / \mathrm{day})$ & $1.59 \pm 0.14$ & $1.47 \pm 0.16$ \\
\hline \multirow[t]{5}{*}{ Feed efficiency } & $\mathrm{FE}_{0-56}(\%)$ & $48.31 \pm 9.70$ & $58.65 \pm 6.47^{*}$ \\
\hline & $\mathrm{FCR}_{0-56}$ & $2.15 \pm 0.47$ & $1.72 \pm 0.18$ \\
\hline & $\mathrm{FCRdm}_{0-56}$ & $1.22 \pm 0.27$ & $0.97 \pm 0.10$ \\
\hline & $\mathrm{PPV}_{0-56}(\%)$ & $16.80 \pm 4.85$ & $23.90 \pm 2.61^{*}$ \\
\hline & $\operatorname{LPV}_{0-56}(\%)$ & $10.12 \pm 4.44$ & $9.74 \pm 0.85$ \\
\hline Condition & $\mathrm{DGl}_{0-56}(\%)$ & $4.34 \pm 1.23$ & $5.55 \pm 1.09$ \\
\hline
\end{tabular}

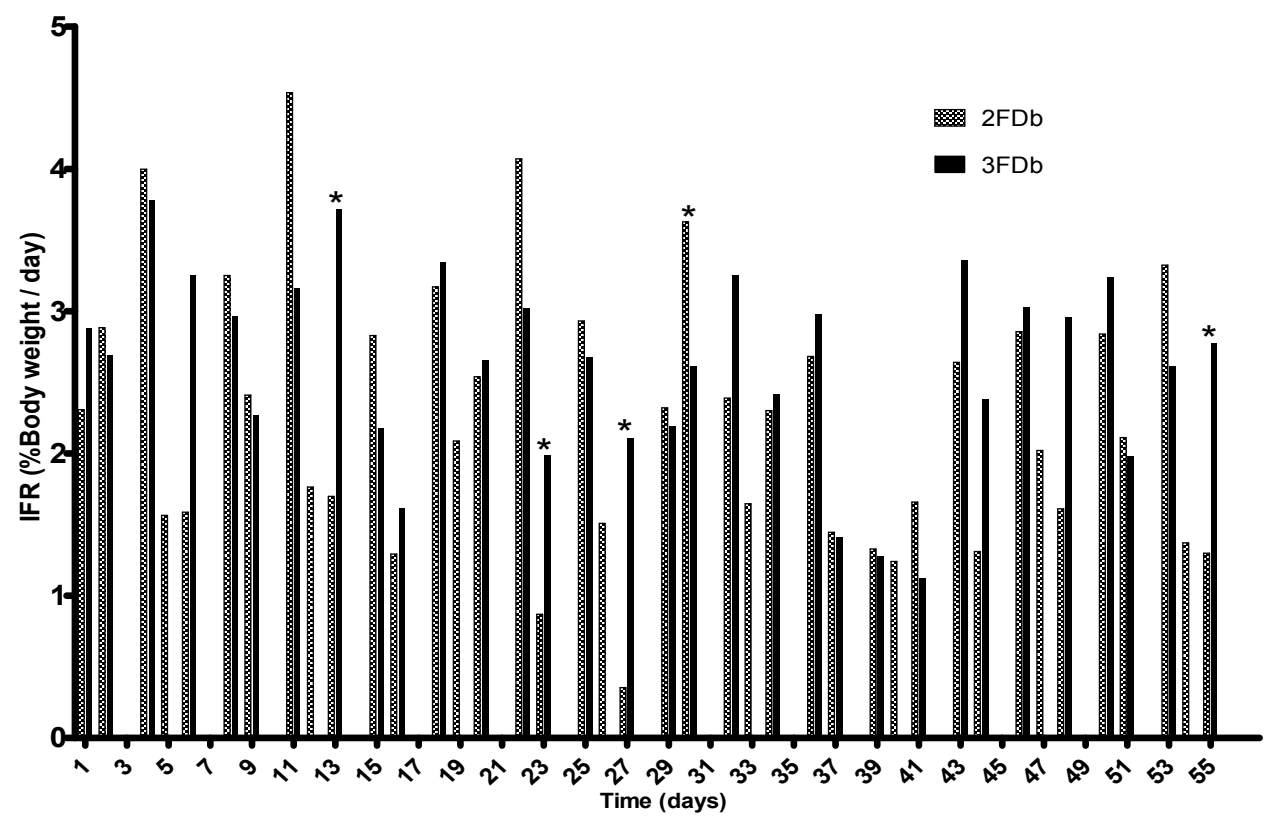

Fig. 1. Instantaneous Feeding Rate (IFR) for two (2FDb) or three (3FDb) fasting days throughout the experiment

${ }^{*} P<0.05$ 
Table 3. Faeces proximate composition (\% dry weight) and apparent digestibility coefficients (ADC) obtained with two (2FDb) or three (3FDb) days of fasting

\begin{tabular}{llll}
\hline Index/Diet & & 2FDb & 3FDb \\
\hline Proximate composition & Crude protein & $17.69 \pm 2.42$ & $16.14 \pm 1.43$ \\
& Crude lipid & $24.46 \pm 1.03$ & $26.28 \pm 5.22$ \\
& Ash & $29.70 \pm 1.50$ & $28.34 \pm 1.98$ \\
& NFE & $28.15 \pm 3.33$ & $29.25 \pm 5.03$ \\
ADC & AIA & $0.7092 \pm 0.1811$ & $0.8654 \pm 0.1894$ \\
& ADCDM & $86.22 \pm 3.25$ & $88.78 \pm 2.57$ \\
& ADCPROT & $96.30 \pm 1.02$ & $97.23 \pm 0.86$ \\
& ADCL & $84.78 \pm 3.67$ & $86.46 \pm 4.83$ \\
No differences found in any comparison (P>O.05). NFE- Nitrogen-free extract, calculated by difference; AIA- Acid \\
Insoluble Ash; ADCDM- apparent digestibility coefficients of the dry matter; ADCPROT- apparent digestibility \\
coefficients of the protein; ADCL- apparent digestibility coefficients of the lipids; ADCNFE- apparent digestibility \\
\end{tabular}

Table 4. Macronutrient composition (\% dry weight) of the different fractions of common octopus fed applying two different feeding schemes: two (2FDb) or three (3FDb) days of fasting

\begin{tabular}{llll}
\hline & & 2FDb & 3FDb \\
\hline Digestive gland & Moisture & $62.12 \pm 6.57$ & $56.38 \pm 0.93$ \\
& Crude protein & $43.57 \pm 11.16$ & $39.40 \pm 3.69$ \\
& Crude lipid & $44.28 \pm 13.77$ & $53.14 \pm 6.91$ \\
& Ash & $3.77 \pm 1.41$ & $3.12 \pm 0.89$ \\
\multirow{4}{*}{ Muscle } & NFE & $8.39 \pm 2.83$ & $4.34 \pm 4.76$ \\
& Moisture & $81.09 \pm 0.81$ & $80.86 \pm 1.26$ \\
& Crude protein & $81.76 \pm 3.02$ & $76.72 \pm 3.55$ \\
& Crude lipid & $2.44 \pm 0.18$ & $2.72 \pm 1.80$ \\
\multirow{4}{*}{ Whole animal } & $11.56 \pm 0.73$ & $11.43 \pm 1.36$ \\
& Ash & $4.24 \pm 3.14$ & $9.13 \pm 4.52$ \\
& NFE & $79.66 \pm 1.27$ & $79.04 \pm 1.04$ \\
& Moisture & $73.55 \pm 3.02$ & $74.24 \pm 3.17$ \\
& Crude protein & $5.89 \pm 1.84$ & $4.95 \pm 0.20$ \\
& Crude lipid & $10.74 \pm 1.23$ & $10.10 \pm 0.75$ \\
& Ash & $9.82 \pm 4.12$ & $10.71 \pm 3.74$ \\
\hline
\end{tabular}

No differences found in any comparison $(P>0.05)$. NFE $=$ Nitrogen free extract

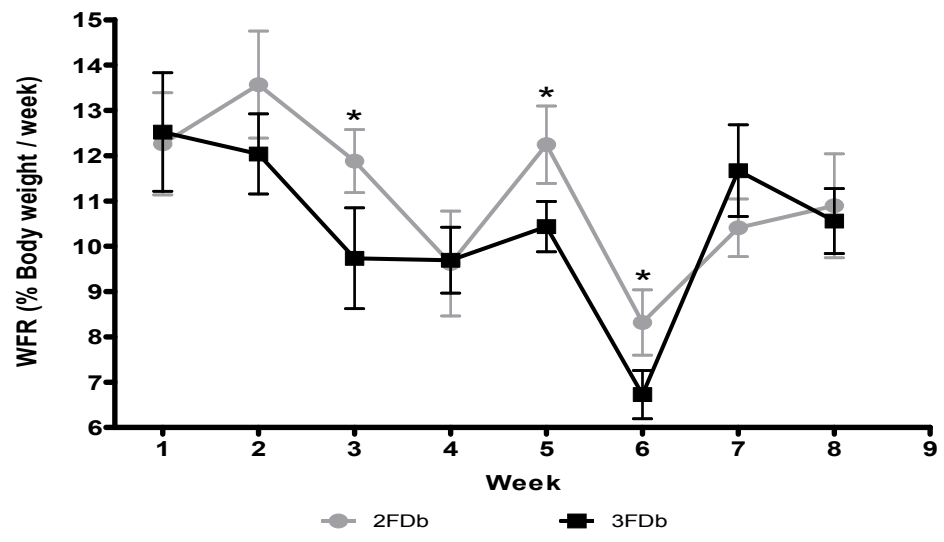

Fig. 2. Feeding Rate per Week (WFR) for both fasting protocols, 2FDb and 3FDb ${ }^{*} P<0.05$ 


\subsection{Discussion}

It seems that $O$. vulgaris subadults display a similar ingestion behaviour (see Fig. 1) as observed in fish species after fasting. In fact, Skalski et al. [22] reported that fish usually show higher food intake after fasting. Moreover, Ali et al. [10] recognized hyperphagia as a mechanism of growth compensation, which is characterized by a higher food intake after fasting by fish that are continuously fed ad libitum. The duration of hyperphagia depends on the frequency and duration of fasting, and food consumption might be equal or higher than in common conditions [10].

Ali et al. [10] did not observe growth depression when fish were starved for short periods with enough food being supplied between fasting episodes, but higher food intake rate was verified. Hence, it seems that growth depression was avoided with similar ingestion by octopus in the present experiment.

The obtained results with 0 . vulgaris were according to those reported by Teskeredžic et al. [23], who had already verified no differences in growth or body composition of rainbow trout fed daily or three times per week.

In the present study, no differences were found between 2 or 3 days of non-consecutive fasting, which indicates that octopus fed on this prepared diet were able to store enough reserves to be used to maintain the homeostasis during fasting. $O$. vulgaris is known for having the ability to regulate food intake when a previous meal was ingested in short-term [24]. Therefore, individuals experience fasting in nature and have the ability to adapt its metabolism to these specific conditions, as described in S. officinalis $[15,16]$.

After fasting, both groups displayed higher foodintake as compensation. On the other hand, both groups displayed a similar trend of food intake when data were normalized as weekly foodintake. It is interesting that FE was better with 3 days of fasting, while no statistical differences were identified regarding FCR probably due to individual data variability.

Interestingly, both treatments displayed a similar trend on feed intake, growth and conversion to those obtained by García García and Cerezo Valverde [11] in octopus fasted and fed on a crab-based diet (Fig. 3). These authors obtained similar Specific Feeding (SFR), Specific Growth
(SGR) and Food Conversion Rates (FCR) on animals fed with crab when comparing daily food supply with 1 fasting day per week. However, 2 fasting days per week caused a significant reduction in SFR and FCR, while SGR was similar. Analogously, despite statistical differences were not verified for any index, a similar trend was verified on mean values supplying the FDb formulated diet when increasing fasting from 2 to 3 days per week: SGR displayed a slight increase while FCR was slightly reduced (Fig. 3).

At the moment, octopus ongrowing development at industrial scale is limited by scarce specific production technology, i.e. the absence of massive production of paralarvae and juveniles in hatcheries, which implies the capture of wild juveniles, and the lack of a commercial feed that promotes high growth and survival. Specific economic studies performed on the production of octopus fed on natural diets, i.e. by-catch species with low commercial value, reared in sea cages related high-risk and low-profit to this activity. In these, juveniles capture and feeding were referred as the main production costs: $40 \%$ and $12 \%$ in the NE of Spain [25] or $17-23 \%$ and $38-40 \%$ in the Mediterranean coast [1], respectively. Wild subadults and food price are dependent on availability and market demand fluctuations. When using formulated diets, the costs of feed must consider the cost of raw materials but also those related to the ingredients processing and diet preparation. Independently of feed, this study was conducted with isolated individuals fed a formulated diet and further research must be performed to quantify the real relevance on profitability of the obtained results at industrial scale. In this sense, it is important to consider mortality on octopus reared in group. In the latter, octopus mortality is frequently observed after high-stress conditions or results from cannibalism and is significantly dependent on the food supplied (either fish or crab), stocking density, temperature, weight and size dispersion [26].

Studies regarding feeding were performed supplying natural food and reported lower mortality rates when crustaceans were used compared to fish [26]. In this sense, a commercially formulated feed will need to be nutritionally balanced and possess organoleptic characteristics to promote ingestion and similar growth performance to those obtained with crustaceans while enhancing efficiency. Rodríguez et al. [27] established $10 \mathrm{~kg} \mathrm{~m}-3$ as 

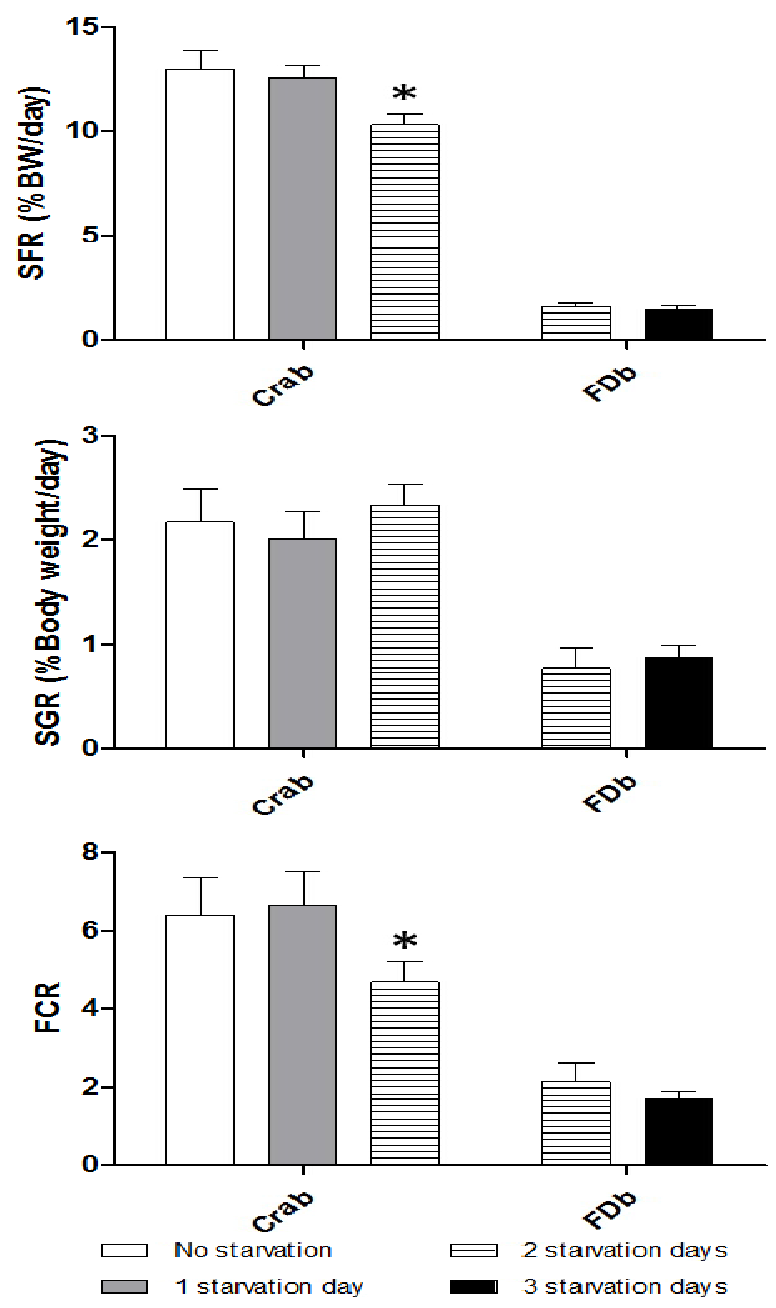

Fig. 3. Specific feeding rate (SFR, \% body weight/day), specific growth rate (SGR, \% body weight/day), and food conversion rate (FCR) obtained from the present feeding regimes (2FDb and $3 F \mathrm{Fb}$ ) and compared with those fed with crab [11]

* $(P<0.05)$ Statistical differences assessed independently for each diet

the optimal initial stock density but García García et al. [26] initially established $6.6-35.2 \mathrm{Kg} \mathrm{m}-3$ reaching $46 \mathrm{~kg} \mathrm{~m}-3$ without observing an impact in growth or survival. A temperature negative effect might be avoided maintaining temperature within the optimal temperature range for common octopus $[27,28]$ of $15-21^{\circ} \mathrm{C}$. Since octopus was individually stocked in tanks, the present study didn't test cannibalism while this might be a relevant factor affecting mortality when animals are grown in groups. Since octopuses living in the wild are subjected to fasting/starvation, food supply was estimated applying wide individual margins (minimum 5\%BW/day) to ensure an ad libitum feeding scheme. Following this reasoning, when octopus is to be reared in group, the food supply should be estimated according to the total biomass (minimum 5\%biomass/day). In contrast, Chapela et al. [29] observed that stressed or malnourished smaller dominated animals, due to the establishment of hierarchies in octopus groups, were more likely to die. García et al. [26] also found an inverse relation between survival and size dispersion, highlighting the relevance of homogeneous sizes in grouped reared octopus.

\section{CONCLUSION}

Growth, survival, proximate composition of octopus and digestibility were not influenced by a feeding regime including either fasting for 2 or 3 
non-consecutive days. $O$. vulgaris subadults seem to have the ability to compensate fasting through an increase in food intake on a subsequent day.

The application of feeding schemes that include fasting days is in accordance with the natural feeding pattern described for this species but is also an interesting option for industrial application, since it promotes a reduction on operational costs achieving similar growth and FE when supplying a formulated diet. In fact, our group current research is focused on octopus grouped rearing applying fasting protocols. Despite the interesting results obtained in the present preliminary study, octopus production at commercial scale is still hampered by the high costs related to food and the purchase of live juveniles. Still, the present results indicate that fasting may be a way to reduce one of the main production costs, the amount of feed. In this sense, further research is needed to achieve a sustainable feed that will allow a massive production of juveniles.

\section{ETHICAL APPROVAL}

All authors hereby declare that "Principles of laboratory animal care" (NIH publication No. 8523, revised 1985) were followed, as well as specific national laws where applicable. All experiments have been examined and approved by the appropriate ethics committee.

\section{ACKNOWLEDGEMENTS}

This work was funded by "Instituto Nacional de Investigación y Tecnología Agraria y Alimentaria" (INIA-Project RTA2012-00072-00-00). T. Rodríguez González wishes to thank Number 37 INIA-CCAA (FPI-INIA) 2014 Grant. A.V. Sykes wishes to thank Fundação para a Ciência e Tecnologia (FCT) his Post-Doc grant (SFRH/BPD/36100/2007) and Investigator FCT contract (IF/00576/2014).

\section{COMPETING INTERESTS}

Authors have declared that no competing interests exist.

\section{REFERENCES}

1. García García J, García García B. Econometric model of viability/profitability of octopus (Octopus vulgaris) ongrowing in sea cages. Aquac. Int. 2011;19:1177.

DOI: $10.1007 / \mathrm{s} 10499-011-9432-1$

2. Vaz-Pires $P$, Seixas $P$, Barbosa $A$. Aquaculture potential of the common octopus (Octopus vulgaris Cuvier, 1797): A review. Aquaculture. 2004;238:221-238.

DOI: 10.1016/j.aquaculture.2004.05.018

3. Cerezo Valverde J, Hernández MD, Aguado-Giménez F, García García B. Growth, feed efficiency and condition of common octopus (Octopus vulgaris) fed on two formulated moist diets. Aquaculture. 2008;275:266-273.

DOI: 10.1016/j.aquaculture.2008.01.012

4. Cerezo Valverde J, Hernández MD, Aguado-Giménez F, Morillo-Velarde PS, García García B. Performance of formulated diets with different level of lipids and glutamate supplementation in Octopus vulgaris. Aquac. Res. 2013;44:1952-1964. DOI: 10.1111/j.1365-2109.2012.03201.x

5. Morillo-Velarde PS, Cerezo Valverde J, Hernández MD, Aguado-Giménez $F$, García García B. Growth and digestibility of formulated diets based on dry and freeze-dried ingredients in the common octopus (Octopus vulgaris). Aquaculture. 2012;368:139-144.

DOI: 10.1016/j.aquaculture.2012.09.028

6. Morillo-Velarde PS, Valverde JC, García García B. A simple format feed to test the acceptability of ingredients for common octopus (Octopus vulgaris Cuvier, 1797). Aquac. Res. 2015;46:994-1000.

DOI: 10.1111/are.12233

7. Boucher-Rodoni R, Boucaud-Camou E, Mangold K. Feeding and digestion. In Cephalopod Life Cycles; Boyle, P. R., Ed.; Academic Press, London. 1987;85-108.

8. Lovell T. Nutrition and feeding of fish. Media, S. S. \& B., Ed.; 2nd ed.; 1998. ISBN 0412077019, 9780412077012.

9. Eroldoğan OT, Kumlu M, Kiris GA, Sezer B. Compensatory growth response of Sparus aurata following different starvation and refeeding protocols. Aquac. Nutr. 2006;12:203-210.

DOI: 10.1111/j.1365-2095.2006.00402.x

10. Ali M, Nicieza A, Wootton RJ. Compensatory growth in fishes: $A$ response to growth depression. Fish Fish. 2003;4:147-190.

DOI: 10.1046/j.1467-2979.2003.00120.x 
11. García BG, Valverde JC. Influencia del número de días de ayuno a la semana sobre el crecimiento, el índice de conversión y la supervivencia en el Pulpo de Roca (Octopus vulgaris Cuvier, 1797). Rev. Aquat. 2004;21:34-41.

12. García-Garrido S, Hachero-Cruzado I, Garrido D, Rosas C, Domingues P. Lipid composition of the mantle and digestive gland of Octopus vulgaris juveniles (Cuvier, 1797) exposed to prolonged starvation. Aquac. Int. 2010;18:12231241.

DOI: $10.1007 /$ s10499-010-9335-6

13. García-Garrido S, Hachero-Cruzado I, Rosas C, Domingues P. Protein and amino acid composition from the mantle of juvenile Octopus vulgaris exposed to prolonged starvation. Aquac. Res. 2013;44:1741-1751.

DOI: 10.1111/j.1365-2109.2012.03180.x

14. Morillo-Velarde PS, Cerezo Valverde J, Llinares RMS, García García B. Energetic contribution of carbohydrates during starvation in common octopus (Octopus vulgaris). J. Molluscan Stud. 2011;77: 318-320.

DOI: 10.1093/mollus/eyr018

15. Lamarre SG, MacCormack TJ, Sykes AV, Hall JR, Speers-Roesch B, Callaghan NI, Driedzic WR. Metabolic rate and rates of protein turnover in food-deprived cuttlefish, Sepia officinalis (Linnaeus 1758). Am. J. Physiol. - Regul. Integr. Comp. Physiol. 2016;310:1160-R1168.

DOI: 10.1152/ajpregu.00459.2015

16. Speers-Roesch B, Callaghan NI, MacCormack TJ, Lamarre SG, Sykes AV, Driedzic WR. Enzymatic capacities of metabolic fuel use in cuttlefish (Sepia officinalis) and responses to food deprivation: Insight into the metabolic organization and starvation survival strategy of cephalopods. J. Comp. Physiol. B Biochem. Syst. Environ. Physiol. 2016;186:711-725.

DOI: $10.1007 / \mathrm{s} 00360-016-0991-3$

17. Estefanell J, Roo J, Guirao R, Afonso JM, Fernández-Palacios $H$, Izquierdo $M$, Socorro J. Efficient utilization of dietary lipids in Octopus vulgaris (Cuvier 1797) fed fresh and agglutinated moist diets based on aquaculture by-products and low price trash species. Aquac. Res. 2012;44(1):93105.

DOI: 10.1111/j.1365-2109.2011.03014.x
18. Morillo-Velarde PS, Cerezo Valverde J, García García B. Utilization of diets with different fish oil content in common octopus (Octopus vulgaris Cuvier, 1797) and resulting changes in its biochemical composition. Aquac. Res. 2015;46:28712884.

DOI: 10.1111/are.12439

19. Rodríguez-González T, Cerezo Valverde J, Sykes AV, García García B. Performance of raw material thermal treatment on formulated feeds for common octopus (Octopus vulgaris) ongrowing. Aquaculture. 2015;442:37-43.

DOI: 10.1016/j.aquaculture.2015.01.035

20. AOAC. Official Methods of Analysis. In The Association of Official Analytical Chemists International; 2003.

21. Zar JH. Biostatistical analysis. Hall, P., Ed.; 5th ed.; 2010. ISBN 0321656865, 9780321656865.

22. Skalski GT, Picha ME, Gilliam JF, Borski RJ. Variable intake, compensatory growth, and increased growth efficiency in fish: Models and mechanisms. Ecology. 2005;86:1452-1462.

DOI: 10.1890/04-0896

23. Teskeredžic Z, Teskeredzic E, Tomec M, Hacmanjek M, McLean E. The impact of restricted rationing upon growth, food conversion efficiency and body composition of rainbow trout. Water Sci. Technol. 1995;31(10):219-223.

DOI: 10.1016/0273-1223(95)00442-P

24. Nixon M. Cephalopod diets. In Cephalopod Life Cycles; Boyle, P. R., Ed.; Academic Press, London. 1987;201-219.

25. García García J, González LMR, García García B. Cost analysis of octopus ongrowing installation in Galicia. Spanish J. Agric. Res. 2004;2:531-537.

26. García García B, Cerezo Valverde J, Aguado-Giménez F, García García J, Hernández MD. Growth and mortality of common octopus Octopus vulgaris reared at different stocking densities in Mediterranean offshore cages. Aquac. Res. 2009;40:1202-1212.

DOI: 10.1111/j.1365-2109.2009.02222.x

27. Rodríguez C, Carrasco JF, Arronte JC, Rodríguez M. Common octopus (Octopus vulgaris Cuvier, 1797) juvenile ongrowing in floating cages. Aquaculture. 2006;254: 293-300.

DOI: 10.1016/j.aquaculture.2005.10.053 
28. Aguado-Giménez F, García García B. Growth and food intake models in Octopus vulgaris Cuvier (1797): Influence of body weight, temperature, sex and diet. Aquac. Res. 2002;40:1202-1212.
29. Chapela A, González ÁF, Dawe EG. Growth of common octopus (Octopus vulgaris) in cages suspended from rafts. Sci. Mar. 2006;70:121-129. DOI: $10.1525 /$ auk.2009.08179

(c) 2018 Rodríguez-González et al.; This is an Open Access article distributed under the terms of the Creative Commons Attribution License (http://creativecommons.org/licenses/by/4.0), which permits unrestricted use, distribution, and reproduction in any medium, provided the original work is properly cited.

Peer-review history:

The peer review history for this paper can be accessed here: http://www.sciencedomain.org/review-history/23065 